\title{
Stækket formand
}

Danmark står klar med et dynamisk logo for EU-formandskabet, men er der rum for dansk dynamik om en krisedagsorden, der afgøres helt andre steder?

Grækenland og Italien er sat under administration af eurozonens stærke. Det rejser spørgsmål om demokratiets skæbne i EU. Debatten om demokratiske mangler i fællesskabet er gammel, men den har helt skiftet overtoner. Nu gælder det ikke så meget manglende folkedeltagelse, men om der er råd til så meget demokrati, når kriser skal løses. Så afsættes ineffektive folkevalgte til fordel for teknokrater og forsøg på løsninger med gængse liberalistiske våben, som er krisens rødder. $\mathrm{Ny}$ tænkning må til, men det kræver inddragelse af aktive folkebevægelser som Occupy. Det kan Danmark bidrage til med debatinitiativer på tværs af EU.

Danmarks formandskab er objektivt styrket af regeringens nej til VKO's grænsekontrol, der viste dansk uvilje til fællesskab. Den danske stemme er også gjort lysere af regeringens værdipolitiske kursskifte om fremmede. Men der står meget tilbage at gøre imod Danmarks image som EU-skeptisk og en af de mest hårdnakkede refuseniks over for euroen, selv om vi indirekte er medlemmer af eurozonen. Og når regeringen ikke tør sende det forbehold til folkeafstemning, vanskeliggør det en indsats for EU-demokratiet. Men ringe forventninger til formandskabet er måske en fordel, da enhver lille sejr kan ses som en succes.

Formandskabet 2012 kan ikke blive en gentagelse af 2002, hvor lyset skinnede over topmødet, der slog EU's døre op for østeuropæiske lande. Danmark stiller med en ambitiøs klimadagsorden, men hovedopgaven bliver den sydeuropæiske krise og et nyt budget, som næppe kan vedtages i formandsperioden. Der kommer blandt andet et fransk præsidentvalg imellem.

Med den danske klimadagsorden kan det gå som for afgående formandsland Polens indsats for at styrke partnerskabet østover, der blev overskygget af arabisk forår og krig i Libyen.

Opgaverne er ikke blevet mindre af, at EU har fået en præsident og en udenrigschef. Opgaverne er vokset, men på de besværlige indre linjer.

Vi betaler nu en høj pris for, at der ikke i tide blev skabt et levende europæisk demokrati for den nødvendige øgede integration. Helle Thorning-Schmidt \& Co kan forhåbentlig bidrage til, at EU's eliter begynder at lytte til civilsamfundene.

\section{Redaktionen}

